\title{
Assessment of Treatment Response and Survival in Patients Diagnosed with Locally Advanced Head and Neck Cancer Treated with Chemoradiotherapy As Part of An Organ-Preservation Treatment Protocol
}

\author{
Lokal İleri Evre Baş Boyun Kanseri Tanısı ile Organ Koruyucu Tedavi Protokolü \\ Olarak Kemoradyoterapi Uygulanan Hastalarda Tedavi Yanıtının ve Sağkalımın \\ Değerlendirilmesi
}

\author{
Hatice Halis ${ }^{1}$, M. Görkem Aksu², Eda Yirmibeşoğlu Erkal'², E. Binnaz Sarper ${ }^{2}$ \\ ${ }^{1}$ Radiation Oncology, Sakarya Univ. Medical Faculty Training and Research Hospital, Dept. of Radiation Oncology Sakarya, Turkey
}

${ }^{2}$ Radiation Oncology Kocaeli Univ. Medical Faculty, Dept. of Radiation Oncology, Kocaeli, Turkey

Yazı̧sma Adresi / Correspondence:

Hatice Halis

Radiation Oncology, Sakarya University Medical Faculty Training and Research Hospital, Department of Radiation Oncology, Sakarya, Turkey T: +90505 2670773 E-mail : haticehalis@hotmail.com

Geliș Tarihi / Received : 11.07.2019 Kabul Tarihi / Accepted : 04.12.2019

Orcid :

Hatice Halis https://orcid.org/: 0000-0002-9938-1856

M. Görkem Aksu https://orcid.org/0000-0001-5532-2742

Eda Yirmibeșoğlu Erkal https://orcid.org/0000-0002-6327-7037

E. Binnaz Sarper https://orcid.org/0000-0001-6840-7569

( Sakarya Tip Dergisi / Sakarya Med J 2019, 9(4):669-678 ) DOI: 10.31832/smj.577344

\footnotetext{
Abstract

Objective This study was carried out to explore the overall survival (OS) and disease-free survival (DFS) rates of patients with locally advanced head and neck cancer who were treated with chemoradiotherapy (CRT).

Materials A total of 54 patients were included in our study. Among 54, 35 were treated with chemoradiotherapy and 19 were treated with radiotherapy only. The tumors were located and Methods in larynx (74\%), hypopharynx (17\%) and oral cavity (9\%). According to TNM stage, among 54 case, one was T1, 10 were T2, 25 were T3 and 18 were T4 stage. Furthermore, 29 were N0, 11 were N1, 13 were N2 and one was N3 stage. The primary tumor was irradiated with conformal or intensity-modulated radiotherapy at an average dose of 70 Gy (64-74), and lymph nodes at a dose of 50 to 70 Gy depending on risk groups. Treatment response, OS and DFS rates were identified in 50 case.

Results The follow-up period ranged from 3 months to 53 months (median=18 months). A clinically and radiologically complete response was observed in 36 ( $72 \%$ ) of 50 patients after 2 months from completion of treatment. A partial response was detected in 12 patients (24\%) and progression in 2 patients (4\%). The rates of OS and DFS over the period of 3 years were found to be $51 \%$ and $58 \%$, respectively. The most common side effect was mucositis detected in $40 \%$ of the patients. The most common side effects of systemic treatment were nausea, vomiting and leukopenia (34\%). Dry mouth was found to be the most frequent late side effect.

Conclusion Radical radiotherapy or chemoradiotherapy is an alternative treatment method of locally advanced head and neck tumors, with acceptable toxicity rates.

Keywords Head and neck cancer; locally advanced stage; radiotherapy; chemoradiotherapy
}

Öz

Amaç Bu çalışma, kemoradyoterapi ile tedavi edilen, lokal ileri evre baş boyun kanserli hastaların genel sağkalım ve hastalısız sağkalım oranlarını araştırmak amacıyla yapıldı.

Gereç ve Çalışmamiza kemoradyoterapi alan 35 hasta ve radyoterapi alan 19 hasta olmak üzere toplam 54 hasta dahil edildi. Tümörler larinks (\%74), hipofarinks (\%17) ve oral kavite (\%9) yerleşimli

Yöntemler idi. TNM evresine göre, 54 vakadan biri T1, 10’u T2, 25'i T3 ve 18'i T4 evresindeydi. Ayrica 29'u N0,11'i N1, 13 'ü N2 ve biri N3'tü. Primer tümöre, ortalama 70 Gy (64-74); lenf nodlarina ise risk gruplarına göre 50 ila 70 Gy arasında konformal veya yoğunluk ayarlı radyoterapi uygulandı. Tedavi yanıtı, sağkalım ve hastallksı sağkalım oranları belirlendi.

Bulgular Takip süresi 3 ay ile 53 ay arasında değismekteydi (ortanca $=18$ ay). Tedavinin tamamlanmasından 2 ay sonra, 50 hastanin 36 sinda (\% 72) klinik ve radyolojik olarak tam bir yanit gözlendi. On iki hastada (\% 24) kısmi bir yanit, 2 hastada (\% 4) progresyon tespit edildi. Genel sağkalım ve hastalksız sağkalım oranları 3 yll boyunca strastyla \% 51 ve \% 58 olarak bulundu. En sık görülen yan etki, hastaları\% 40’inda saptanan mukozit idi. Sistemik tedavinin en sık görülen yan etkileri bulantı, kusma ve lökopeni idi (\% 34). Ağız kuruluğu en sik görülen geç yan etkiydi. Sonuç: Radikal radyoterapi veya kemoradyoterapi, lokal ileri evre baș boyun tümörlerinde kabul edilebilir toksisite oranlart ile alternatif bir tedavi yöntemidir.

Sonuç Radikal radyoterapi veya kemoradyoterapi, lokal ileri evre bas boyun tümörlerinde kabul edilebilir toksisite oranları ile alternatif bir tedavi yöntemidir. 


\section{INTRODUCTION}

Head and neck tumors are the sixth most common malignancy in the United States, with an annual incidence of $40,000-50,000$ cases. $^{1}$ The male to female ratio is $2.5: 1.1$ Two thirds of cases presenting to hospitals are at advanced stage. ${ }^{2}$ A total of $90 \%$ of cancers contain squamous cell histology. The most common areas are oral cavity, pharynx, larynx and hypopharynx. ${ }^{1,2}$

A multi-modal approach is the main method of treatment of locally advanced head and neck cancers with squamous cell histology. Although successful results have been achieved with surgery or radiotherapy (RT) + chemotherapy (CT) in early stage patients, studies on organ-preserving approaches in the treatment of locally advanced diseases have been emphasized in recent years.

One of the main applications of chemoradiotherapy (CRT) is to protect functions in locally advanced laryngeal and hypopharyngeal cancers. Initial studies in this area were carried out through neoadjuvant (CT) and two significant studies emerged in the late 1980s and early 1990s. Surgical randomized trials alternative to surgery carried out by the Veterans Affairs Laryngeal Cancer Study Group (VALSG) and the European Organization for Research and Treatment of Cancer (EORTC) have shown that larynx can be preserved without reducing overall survival in laryngeal cancers and hypopharyngeal cancers, respectively. In these studies, the larynx was preserved in $64 \%$ and $42 \%$ of patients, respectively.,

In our study, we aimed to explore the overall survival (OS) and disease-free survival (DFS) rates of patients with locally advanced head and neck cancers who underwent CRT as part of an organ-preservation treatment protocol.

\section{MATERIALS and METHODS}

In this study, 54 cases of non-metastatic head and neck cancer with locally advanced histopathological diagnosis were reviewed retrospectively and a retrospective cohort study designed. The data was obtained from the cases treated and followed-up between December 2006 and December 2010 in the Radiation Oncology Department at Kocaeli University. In staging the cancers, the American Joint Committee for Cancer Staging System 2010 (AJCC) was used to evaluate patients with tumors located in the oral cavity, larynx, and hypopharynx. ${ }^{5}$ The ethical approval was obtained from Ethical Committee of Kocaeli University Medical Faculty with the date and number 13.06.2011 and 2011/68 respectively.

All of the cases were evaluated before treatment by a multidisciplinary group formed by a radiation oncologist, head and neck specialist and a medical oncologist. The head and neck region of cases were assessed by endoscopy, computerized tomography (CT) or magnetic resonance imaging (MRI) in terms of tumor location and local spread. All patients were evaluated prior to treatment by complete blood counts, electrolytes, liver enzymes, renal function tests, and chest X-Ray or thorax CT. Performances of the patients were evaluated based on the Eastern Cooperative Oncology Group Performance Status (ECOG-PS) scale.

\section{Treatment Plan \\ Chemotherapy}

As the induction CT, $75 \mathrm{mg} / \mathrm{m}^{2}$ cisplatin was introduced via infusion for 90 minutes on the 1st day, and $750 \mathrm{mg} / \mathrm{m}^{2}$ fluorouracil was introduced via infusion for 24 hours on the 1 st and 5th days, 3 doses every 21 days. The patients who were not able to receive cisplatin because of age and performance were treated once with $400 \mathrm{mg} / \mathrm{m}^{2}$ cetuximab one week before RT and with $250 \mathrm{mg} / \mathrm{m}^{2} /$ week cetuximab afterwards.

Concomitantly $75-100 \mathrm{mg} / \mathrm{m}^{2}$ cisplatin was administered every 3 weeks 2 or 3 times for 90 minutes via infusion. And, $30 \mathrm{mg} / \mathrm{m}^{2}$ cisplatin was administered weekly $4-6$ times depending on patient tolerability. 


\section{Radiotherapy}

Images of the cases to be used in the $3 \mathrm{D}$ radiotherapy (3DRT) planning were obtained using a Siemens Somatom Emotion Duo computerized tomography device. During the imaging, immobilization was achieved using a thermoplastic mask.

All cases were treated using a 3DRT device. The primary tumor was irradiated with RT at an average dose of $70 \mathrm{~Gy}$ (64-74) for 7 weeks in 2 Gy fractions per day, and lymph nodes at an average dose of 60 Gy (50-68) in 2 Gy factions.

\section{Treatment Evaluation}

The patients were evaluated 2 months after the completion of concomitant RT/CRT. Tumor response was evaluated by the head and neck specialist through an endoscopic examination and a physical examination. It was evaluated radiologically through by CT or an MRI scan.

\section{Follow-Up and Statistical Method}

For first year, cases were checked once every two months after RT, and then once every three months during the study period. During the follow-ups, routine blood and biochemical examinations, and head and neck examinations of the patients were requested in addition to their physical examinations.

OS and DFS analyzes were calculated beginning from the date of biopsy. Statistical analyses were carried out using the SPSS statistics 17.0 software (SPSS Inc.). The primary endpoint of the study were OS and DFS. OS was defined as the period from the time of the clinical examination and the radiological imaging when a progression was observed after standard treatment, to the time of the last check-up or death. DFS was defined as the period from the time of the clinical examination and the radiological imaging when a progression was observed after standard treatment, to the time of the clinical examination and the radiological imaging when a progression was observed after salvage treatment. For patients who died without any known disease progression, we censored the DFS data at the time of their last follow-up or death.

\section{RESULTS}

\section{Patient Characteristics}

The follow-up periods of the cases were between 3 and 53 months, and the median was 18 months. Four patients were excluded from the statistical analyses because they died within 1 to 4 weeks following RT (1 patient was excluded due to comorbid diseases, 2 patients due to progression of the disease and 1 patient was excluded due to renal toxicity). A total of 50 cases were evaluated. The youngest of the cases was 39, and the oldest case was 84 at the time of diagnosis, and the median age was 64 . Considering gender, 39 of our cases were male (78\%), and 11 of them were female (22\%). Our cases were evaluated based on the performance assessment (ECOG-PS) scale. Most of the cases exhibited a performance value of 0 (zero) according to ECOG-PS. The location of tumor in the majority of the cases was larynx (74\%), followed by hypopharynx (19\%) and oral cavity (9\%). A great majority of the cases (89\%) had stage III or IV disease and $2 \%$ stage I and $9 \%$ stage II. The cases with stage I and II disease did not accept an operation, had good performance and were subjected to an organ-preservation protocol. According to TNM stage, among 54 case, one was T1, 10 were T2, 25 were T3 and 18 were T4 stage. Also 29 were N0, 11 were N1, 13 were N2 and one was N3 stage. A total of 19 (35\%) of 54 cases were treated with radiotherapy (RT) only, and 35 (65\%) cases with CRT (2 patients were treated with CRT after induction CT). The primary tumor was irradiated with RT at an average dose of 70 Gy (64-74) for 7 weeks in 2 Gy fractions per day, and lymph nodes at an average dose of 60 Gy (5068 ) in 2 Gy factions. Chemotherapy was administered to 35 patients ( 2 cases received induction CT). Among 35 patients, 17 (59.5\%) were treated with cisplatin 75-100 mg/ $\mathrm{m}^{2}$ per 3 weeks and 14 (49\%) were treated with $30 \mathrm{mg} / \mathrm{m}^{2}$ per week. Four cases who were not able to receive cisplatin because of age and performance status were treated 400 $\mathrm{mg} / \mathrm{m}^{2}$ cetuximab one week before RT in first cycle and 
with $250 \mathrm{mg} / \mathrm{m}^{2}$ cetuximab per week afterwards.

\section{Treatment Results}

After treatment period, disease response evaluation was done. Among 50 patient, 36 (72\%) achieved complete response, 12 (24\%) achieved partial response and $2(4 \%)$ had disease progression. Table 1 shows treatment response during the 2 nd month

Table 1. Treatment response during the 2nd month

\begin{tabular}{|l|c|c|}
\hline Treatment response & Count (n) & Percentage (\%) \\
\hline Complete Response & 36 & 72 \\
\hline Partial response & 12 & 24 \\
\hline Progressive disease & 2 & 4 \\
\hline Total & 50 & 100 \\
\hline
\end{tabular}

Considering the type of treatment administered to the cases, only 11 (61.1\%) of the 18 patients treated with RT, and $25(78.1 \%)$ of the 32 patients treated with CRT had complete response. Table 2 shows the treatment responses according to treatment method.

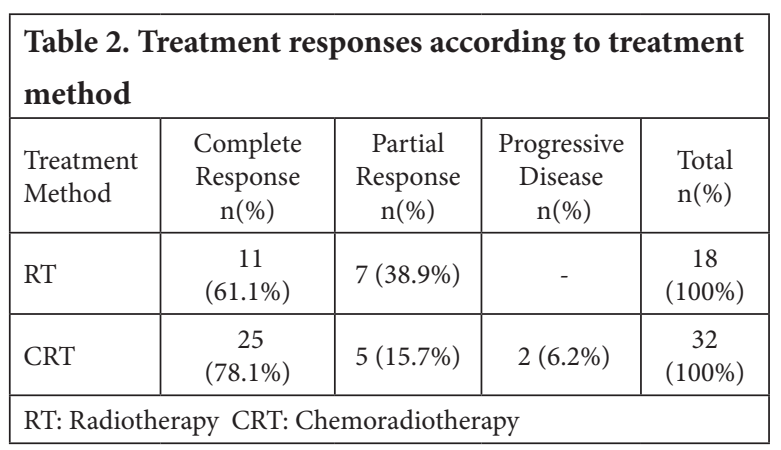

Disease progression was observed in two patients. These patients were unable to tolerate any treatment and died due to the progression of the disease.

Partial response was observed in one patient who was treated with CT after surgery. He lived without any sign of disease. Two patients were treated with CT only. Nine patients were not given any treatment due to poor performance, and 11 patients died due to the progression of the disease.

In 3 of 36 patients with complete response, a local-regional recurrence was detected in 9-36 months (median=23). Two patients underwent a primary surgery. One patient who was considered inoperable was treated with chemotherapy. Two patients died due to the progression of the disease, and one patient lived disease-free. Five patients with complete response died due to comorbidities.

In $7(14 \%)$ of the 50 patients who were treated, distant metastases were found in the 7-19 months (median=11) following the treatment. Distant metastases were detected in the liver in 6 patients, and in the lung in 1 patient. Three patients were treated with multi-agent chemotherapy. No treatment was given to 4 patients due to poor performance. Six patients died due to metastasis.

\section{Overall Survival and Disease-Free Survival}

In our clinic, we analyzed 50 patients whose post-treatment responses were evaluated through post-treatment physical examinations and radiological examinations. The patients with complete response (36 patients) had a survival period of $8-53$ months (median $=22$ months). This duration was $7-23$ months (median=12 months) in the patients with partial response (12 patients) and 5-7 months in the patients with progression (2 patients). The survival period was 7-22 months (median=20 months) in 7 patients with metastasis. Overall survival over the 3-year period was found to be $51 \%$. Disease-free survival over the 3 -year period was found to be $58 \%$.(Figure 1, Figure 2)

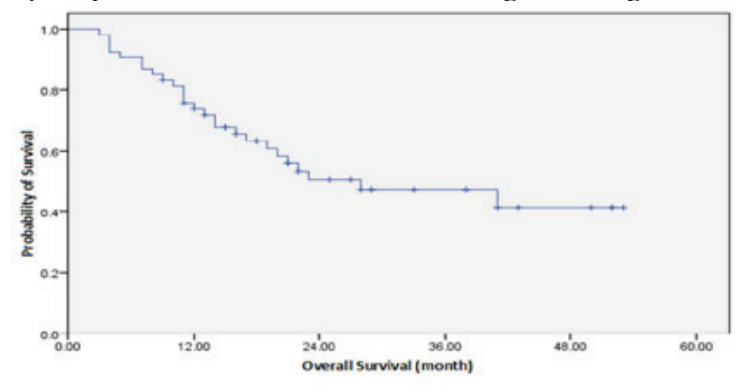

Figure 1. 3-Year overall survival 


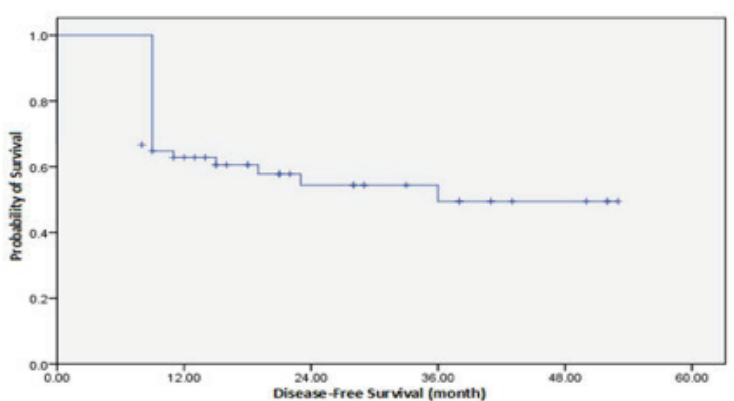

Figure 2. 3-Year disease-free survival

\section{Toxicity}

In most of the cases, systemic side effects such as nausea and vomiting and local side effects such as mucositis, dermatitis and dysphagia at different rates were observed during the treatment. The most common side effect was mucositis detected in $40 \%$ of the patients. The most common side effects of systemic treatment were nausea, vomiting and leukopenia which determined in $34 \%$ of the patients. Dry mouth was found to be the most frequent late complication. One patient who was died (grade V) due to renal toxicity after CRT, was not included in the statistical. Table 3 shows the side effects that developed during the treatment.

\begin{tabular}{|l|c|c|}
\hline \multicolumn{3}{|c|}{ Table 3. Side effects during treatment } \\
\hline & $\begin{array}{c}\text { Grade I-II } \\
\mathbf{n}\end{array}$ & $\begin{array}{c}\text { Grade III-IV } \\
\mathbf{n}\end{array}$ \\
\hline Nausea and vomiting & 10 & - \\
\hline Anemia & 5 & - \\
\hline Thrombocytopenia & 1 & - \\
\hline Leukopenia & 7 & - \\
\hline Mucositis & 20 & 6 \\
\hline Dermatitis & 15 & 2 \\
\hline
\end{tabular}

\section{DISCUSSION}

Head and neck squamous cell cancer (HNSCC) is the 6th most common cancer in the world. ${ }^{2}$ Two thirds of cases presenting to hospitals are at advanced stage. ${ }^{3}$ In the locally advanced stage disease, local recurrence is observed at a rate of $50-60 \%$ and distant metastasis at a rate of $20-30 \%$ within an average of 2 years after treatment. ${ }^{6,7}$ In head and neck cancers, the standard treatment is surgery and/ or RT. The choice of treatment may differ depending on the localization, stage, and operability of the tumor, and the clinical experience of the physician. Surgery or RT can be used alone for early stage tumors without regional lymph node involvement. ${ }^{8}$ Simultaneous CRT, however, is the most suitable option in cases where the anatomic location and spread of the tumor restrict surgical intervention. ${ }^{9}$ Although the long-term treatment results of locally advanced HNSCC have not yet been encouraging, CRT has been proven to provide more survival and local control advantages compared to RT. ${ }^{10-12}$

Systemic CT may be administered prior to local regional treatment (induction), after, and concurrently with RT as part of a combined treatment. The purpose of administering induction CT is to eradicate the microscopic disease in vascularized tumors by reducing tumor volume more rapidly. ${ }^{7,13}$

In the literature, head and neck tumors are more common in males. The male to female $(\mathrm{M} / \mathrm{F})$ ratio is $2.5 / 1$. The incidence increases in middle ages and hits a peak in the 60-75 age group. ${ }^{1}$

In our study, an assessment of the cases according to gender also revealed that 39 of the cases (78\%) were males and $11(22 \%)$ were females, and the incidence was more common in males. Moreover, the disease was seen more commonly in advanced ages, in parallel with the literature. A head and neck tumor was seen in 1 person aged 30-39 (2\%), 7 people aged $40-49$ (14\%), 13 people aged 50-59 (26\%), 17 people aged 60-69 (34\%) and 12 people aged 70 or over $(24 \%)$.

One of the main uses of CRT is to protect functions in locally advanced laryngeal and hypopharyngeal cancers. Initial studies in this area were carried out through neo- 
adjuvant chemotherapy, and two significant studies emerged in the late 1980s and early 1990s. Surgical randomized trials alternative to surgery carried out by the Veterans Affairs Laryngeal Cancer Study Group (VALSG) and the European Organization for Research and Treatment of Cancer (EORTC) have shown that larynx can be preserved without reducing overall survival in laryngeal cancers and hypopharyngeal cancers, respectively. In these studies, the larynx was preserved in $64 \%$ and $42 \%$ of patients, respectively. ${ }^{3,4}$

In the trial study of VALSG, 332 patients with stage III-IV laryngeal cancer were randomized into two arms. One of the arms was treated with total laryngectomy followed by adjuvant RT. The other arm was treated with PF induction chemotherapy, and the patients with response were given RT. In the arm with induction, the patients with partial or no response to CT were operated. As a result, 2-year (68\%) and 10-year OS were found to be the same on both arms. Local recurrence was better in the arm which had not been operated $(\mathrm{p}=.001)$, and distant metastasis was less in the arm with induction $\operatorname{arm}(\mathrm{p}=.001)$. In the arm with induction, the rate of 2-year laryngeal preservation was found to be $66 \%{ }^{4}$

In the laryngeal preservation study of EORTC, 202 patients with hypopharyngeal cancer (T2-4, N0-2b) were evaluated. One arm was treated with surgery followed by RT. The other arm was treated with induction CT (cisplatin $+5 \mathrm{FU})$, and only the patients who achieved full response were treated with RT. OS was found to be superior in the organ preservation arm in the 3 rd year (57\% versus $43 \%$ ) and similar in the 5 th year (38\% versus $33 \%){ }^{3}$ Distant metastasis was more frequent in the surgery arm (36\% versus $25 \%$ ), while locoregional control was found to be similar in both arms. ${ }^{3}$

The phase-III randomized trial of the Radiation Therapy Oncology Group (RTOG) 91-11 included 547 cases with stage III-IV laryngeal cancer. The results of RT, simul- taneous cisplatin with RT, and RT only were compared following the administration of induction CT (cisplatin +5 -FU). There was no statistically significant difference between the 3- and 5-year OS durations (54\%, 59\%, and $55 \%$ at 5 years, respectively). CRT was found to be superior in terms of local and regional control. In the 5-year follow-up, laryngeal preservation was found in $66 \%$ of the patients of the RT arm, 70\% of the induction arm, and $84 \%$ of the concurrent arm $(\mathrm{p}=.003)$. Concurrent cisplatin and RT became the standard laryngeal preservation protocol after the RTOG 91-11 study. ${ }^{14}$

In our study, 19 (35\%) of the 54 cases were treated with RT only, and 35 (65\%) cases with CRT (2 patients were treated with CRT after induction CT). All of the cases were treated using a 3D conformal RT device. The primary tumor was irradiated with RT at an average dose of 70 Gy (64-74) for 7 weeks in 2 Gy fractions per day, and lymph nodes at an average dose of 60 Gy (50-68) in 2 Gy factions. Concomitant CRT was administered to 35 (65\%) of the cases, and it was administered to 2 cases after induction CT. A case receiving induction CT was given $75 \mathrm{mg} / \mathrm{m}^{2}$ cisplatin on the 1st day, and $750 \mathrm{mg} / \mathrm{m}^{2}$ fluorouracil on the 1 st and 5 th days, 3 doses every 21 days, followed by $30 \mathrm{mg} / \mathrm{m}^{2} /$ week cisplatin plus RT. The other case receiving induction CT was given $75 \mathrm{mg} / \mathrm{m}^{2}$ cisplatin and $75 \mathrm{mg} / \mathrm{m}^{2}$ epirubicin on the first day, and RT with $250 \mathrm{mg} / \mathrm{m}^{2}$ cetuximab per week due to toxicity. Four cases (1.5\%) who were not able to receive cisplatin because of age and performance were treated once with $400 \mathrm{mg} / \mathrm{m}^{2}$ cetuximab one week before RT and with $250 \mathrm{mg} / \mathrm{m}^{2} /$ week cetuximab afterwards concurrently with RT. A total of 17 cases (59.5\%) were given $75-100 \mathrm{mg} / \mathrm{m}^{2}$ cisplatin concurrently with RT every 3 weeks. Because of hematologic side effects, CT was administered once in 2 of the patients who received cisplatin every 3 weeks. And, 14 cases (49\%) were given $30 \mathrm{mg} / \mathrm{m}^{2} /$ week cisplatin concurrently with RT. Considering the types of treatment administered to the cases in our clinic, only 11 (61.1\%) of 18 patients treated with RT, and 25 (78.1\%) of 32 patients treated with CRT had complete response. The- 
se results, which were similar to the literature, were found to be superior in the CRT receiving group to the RT receiving group in terms of treatment response.

Considering the rates of OS in our study, the results were again superior in the group receiving CRT. The patients with complete response (36 patients) had a survival period of 8-53 months (median=22 months). This duration was 7-23 months (median=12 months) in the patients with partial response (12 patients) and 5-7 months in the patients with progression ( 2 patients). The survival period was 7-22 months (median=20 months) in 7 patients with metastasis. When all patients were considered together, the 3-year OS was found to be $51 \%$.

In the study of Medina et al., the most common acute toxicity in patients receiving weekly cisplatin was shown to be mucositis, which was found in $85 \%$ of patients and reached the grade 3 level. Moreover, different rates of side effects such as grade 3 neutropenia, grade 3 thrombocytopenia and anemia were reported, and the side effects were found to be higher in the group receiving concurrent CRT. ${ }^{15}$

In our study, the response rates of all of the cases were assessed through clinical examinations and radiologic imaging after 2 months of treatment, as well. When the tumor response rates were examined, it was found that $36(72 \%)$ of the 50 patients achieved complete response, 12 (24\%) achieved partial response and $2(4 \%)$ had progression. The results were found to be superior in the group receiving CRT similar to the literature. Considering the side effects, in most of the cases, systemic side effects such as nausea and vomiting and local side effects such as mucositis, dermatitis and dysphagia at different rates were observed during the treatment. Again, similar to the literature, mucositis was the most common side effect (40\%) developing in the patients. And, dry mouth was found to be the most frequent late complication.

A meta-analysis (MACH-NC) involved the results of
16,485 patients with resectable or irresectable head and neck cancer. The results were reanalyzed in 2009 yielding the following:

- In 9,605 patients receiving concomitant CT with a mean follow-up of 5.6 years, there was no significant increase in the risk of non-cancer related deaths (hazard ratio (HR) .81) compared to the patients receiving definitive local treatment, with a significant reduction in the risk of cancer-related death in the concomitant treatment group.

- In terms of the efficiency of treatment, there was no statistically significant difference between the group over 70 years old receiving concomitant treatment and the group receiving local treatment only.

- When the results of 5,311 patients receiving induction CT were compared with the patients receiving RT only or surgery in terms of OS, no difference was found statistically (HR .96, 95\% CI .90-1.02).

- In the study where concomitant CRT were compared with induction CT over 861 patients, there was no statistically significant difference between the two groups (HR .90, $\mathrm{p}=.15$ ). It was observed that concomitant CRT was more effective in preventing locoregional failures, while induction CT was relatively more successful in preventing distant metastases.

- In terms of OS, there was no significant difference when 2,567 patients treated with adjuvant CT were compared with the group treated with definitive local treatment alone (HR 1.06, 95\% CI .95-1.16).

The results of 3,216 laryngeal cancer patients were evaluated in a comprehensive study by the MACH-NC Collaborative Group in 2011. In this study, it was observed that the general benefit increased with the addition of locoregional treatment to CT (HR .87 for death, 95\% CI .80-.96). However, when the administration of neoadjuvant CT or adjuvant CT was compared with the direct administration of concomitant CRT, the results were shown to favor the concomitant CRT (HR .80, 95\% CI .70-.90). ${ }^{16}$ 
In our study assessing the results of the 50 patients treated in our clinic, only $3(8.5 \%)$ of the 36 patients $(72 \%)$ achieving complete response had local recurrence within 2 years. In 7 (14\%) of these 50 patients, distant metastases were detected 7 to 19 months (median=11 months) after treatment. Our results were similar to those found in the literature in that CRT was found to favor the CRT receiving group, although the groups were not statistically significant due to the low number of patients.

Recent studies (TAX 323, TAX 324 and GORTEC 2000$01)$ investigated the important question of identifying the optimal induction CT regimen to use in head and neck cancer. ${ }^{17-19}$ The TAX 323 study compared induction therapy with docetaxel, cisplatin, and fluorouracil (TPF) to cisplatin and fluorouracil (PF) followed by RT alone. The TAX 324 study compared induction therapy with TPF to cisplatin and PF followed by CRT alone. The GORTEC 2000-01 trial compared induction PF to induction TPF both followed by RT in good responders in larynx and hypophrynx SCC. Those studies showed that TPF was sig- nificantly better than PF for survival, local control, and organ preservation.

Two phase II trials explored the role of cetuximab in laryngeal and hypopharyngeal SCC. The TREMPLIN trial compared RT + cetuximab or CRT (RT+sisplatin) after $\mathrm{TPF}^{20}$ The DeLOS=II trial compared TPF followed by RT with TPF plus cetuximab followed by RT plus cetuximab. ${ }^{21}$ However, these trials failed to indicate an advantage for the incorporation of cetuximab in the treatment paradigm. To date, two approches for laryngeal preservation have been validated: induction TPF followed by RT laryngeal and hypopharyngeal SCC and concurrent CRT for laryngeal SCC. The ongoing French phase III trial (GORTEC 2014-03-SALTORL, clinicaltrials.gov NCT03340896) is comparing induction TPF followed by RT in responders vs. concurrent cisplatin-based chemoradiotherapy with the composite end-point of laryngoesophageal dysfunction-free survival as primary end-point. Selected randomised phase III and phase II studies on organ preservation in advanced laryngeal cancer were summarized in Table 4.

\begin{tabular}{|c|c|c|c|c|c|c|}
\hline \multirow[t]{2}{*}{ Study } & \multirow[t]{2}{*}{ Population } & \multirow[t]{2}{*}{ Treatment arms } & \multicolumn{4}{|c|}{ Outcomes } \\
\hline & & & Parameter & Arm A & Arm B & Arm C \\
\hline \multirow{2}{*}{ VALCSG [4] } & \multirow{2}{*}{$\begin{array}{l}\text { Stage III-IV larynx } \\
332 \text { patients ran- } \\
\text { domised }\end{array}$} & \multirow{2}{*}{$\begin{array}{c}\text { Multicentre randomised phase III study } \\
\text { Arm B: } 3 \text { cycles of PF followed by RT in responders }\end{array}$} & 2 year survival & $68 \%$ & $68 \%$ & \\
\hline & & & Larynx preservation rate & $68 \%$ & & \\
\hline \multirow{4}{*}{$\begin{array}{l}\text { RTOG 91-11 } \\
{[14]}\end{array}$} & \multirow{4}{*}{$\begin{array}{l}\text { Stage III or IV SCC } \\
\text { of the supraglottic or } \\
\text { glottic larynx } \\
547 \text { patients } \\
\text { randomised }\end{array}$} & \multirow{4}{*}{$\begin{array}{l}\text { Arm A: } 3 \text { cycles of PF followed by RT in responders } \\
\qquad \begin{array}{c}\text { Arm B: CRT } \\
\text { Arm C: RT }\end{array}\end{array}$} & $\begin{array}{l}5 \text { year laryngectomy-free } \\
\text { survival }\end{array}$ & $44.6 \%$ & $46.6 \%$ & $33.9 \%$ \\
\hline & & & Larynx preservation rate & $70.5 \%$ & $83.6 \%$ & $65.7 \%$ \\
\hline & & & 5 year locoregional control & $54.9 \%$ & $68.8 \%$ & $51.0 \%$ \\
\hline & & & 5 year overall survival & $59.2 \%$ & $54.6 \%$ & $53.5 \%$ \\
\hline \multirow{3}{*}{$\begin{array}{l}\text { GORTEC 2000- } \\
01[19]\end{array}$} & \multirow{3}{*}{$\begin{array}{l}\text { Stage III -IV SCC of the } \\
\text { larynx or hypopharynx } \\
213 \text { patients ran- } \\
\text { domised }\end{array}$} & \multirow{3}{*}{$\begin{array}{c}\text { Arm A: } 3 \text { cycles of PF followed by RT in } \\
\text { responders } \\
\text { Arm B: } 3 \text { cycles of TPF followed by RT in respond- } \\
\text { ers }\end{array}$} & $\begin{array}{l}\text { Actuarial } 3 \text { year larynx } \\
\text { preservation rate }\end{array}$ & $57.5 \%$ & $70.3 \%$ & \\
\hline & & & $\begin{array}{l}\text { Overall response rate after } \\
\text { induction chemotherapy }\end{array}$ & $59.2 \%$ & $80 \%$ & \\
\hline & & & 3-year overall survival & $60 \%$ & $60 \%$ & \\
\hline \multirow[b]{2}{*}{$\begin{array}{l}\text { TREMPLIN } \\
{[20]}\end{array}$} & \multirow[b]{2}{*}{$\begin{array}{l}\text { Stage III- IV SCC of the } \\
\text { larynx or hypopharynx } \\
153 \text { patients enrolled } \\
115 \text { randomised }\end{array}$} & \multirow{2}{*}{$\begin{array}{c}\text { Multicentre randomised phase II study } \\
3 \text { cycles of TPF followed by response assessment } \\
\text { Responders were randomised to RT with either } \\
\text { concurrent } 3 \text { weekly cisplatin(armA) or concurrent } \\
\text { weekly cetuximab (armB) }\end{array}$} & $\begin{array}{l}\text { Larynx preservation at } 3 \\
\text { months }\end{array}$ & $93 \%$ & $96 \%$ & \\
\hline & & & $\begin{array}{l}\text { Proportion who received } \\
\text { full treatment protocol }\end{array}$ & $45 \%$ & $71 \%$ & \\
\hline
\end{tabular}

SCC,squamous cell carcinoma; TL,total laryngectomy; PF,cisplatin and 5- fluorouracil; TPF, docetaxel,cisplatin and 5- fluorouracil; RT, radiotherapy; CRT, concurrent chemoradiation 
In our study, two cases recieved induction CT. First one treated with PF and followed by cisplatin plus RT. The other one treated with cisplatin, epirubicin and followed by RT plus cetuximab due to toxicity of cisplatin that detected in induction CT. Four cases (1.5\%) who were not able to receive induction $\mathrm{CT}$ because of age and performance status were treated concurrently with cetuximab and RT.

In conclusion, CRT is the standard treatment method in inoperable locally advanced head and neck cancers and in the organ-preservation approach. It is a matter of debate which CT combination and which protocol should be used. Although RT after induction CT offers significant advantages in organ-preservation treatments, local regional failures are still high.

EGFR antagonists may be suggested for patients who are not able to receive CT due to advanced age and performance status. Nevertheless, despite the fact that CRT provides better disease control, there are still many issues that have to be clarified in subsequent studies in terms of a patient and CT scheme selection, patient monitoring in early and late side effects, and processes of supportive treatment in serious side effects. 
Sakarya Med J 2019;9(4):669-678

HALİS et al., Response and Survival in Chemoradiotherapy

\section{References}

1. Jemal A, Murray T, Samuels A, Ghafoor A, Ward E, Thun MJ. Cancer statistics, 2003. CA Cancer J Clin 2003;53:5-26.

2. Jemal A, Siegel R, Xu J, Ward E. Cancer statistics, 2010. CA Cancer J Clin 2010;60:277-300.

3. Lefebvre JL, Chevalier D, Luboinski B, Kirkpatrick A, Collette L, Sahmoud T. Larynx preservation in pyriform sinus cancer: preliminary results of a European Organization for Research and Treatment of Cancer phase III trial. EORTC Head and Neck Cancer Cooperative Group J Natl Cancer Inst 1996;88:890-9.

4. The Department of Veterans Affairs Laryngeal Cancer Study Group. Induction chemotherapy plus radiation compared with surgery plus radiation in patients with advanced laryngeal cancer. N Engl J Med 1991;324:1685-90

5. Edge SB, Byrd DR, Compton CC, Fritz AG, Greene FL, Trotti A, editors. AJCC cancer staging manual 7th ed. New York, NY: Springer, 2010.

6. Forastiere A, Koch W, Trotti A, Sidransky D. Head and neck cancer. N Engl J Med 2001;345:1890-900

7. Posner MR, Haddad RI, Wirth L, Norris CM, Goguen LA, Mahadevan A, et al. Induction chemotherapy in locally advanced squamous cell cancer of the head and neck: evolution of the sequential treatment approach. Semin Oncol 2004;31:778-85.

8. Agrawal $\mathrm{N}, \mathrm{Ha}$ PK. Management of early-stage laryngeal cancer. Otolaryngol Clin North Am 2008; 41:757-69.

9. Scher RL, Esclamado RM. Organ and function preservation: the role of surgery as the optimal primary modality or as salvage after chemoradiation failure. Semin Radiat Oncol 2009; 19:17-23.

10. Pignon JP, le Maître A, Bourhis J, MACH-NC Collaborative Group. Meta-analyses of chemotherapy in head and neck cancer (MACH-NC): an update. Int J Radiat Oncol Biol Phys 2007;69:112-4.

11. Garden AS, Asper JA, Morrison WH, Schechter NR, Glisson BS, Kies MS, et al. Is concurrent chemoradiation the treatment of choice for all patients with Stage III or IV head and neck carcinoma? Cancer 2004;100:1171-8.

12. Brizel DM, Albers ME, Fisher SR, Scher RL, Richtsmeier WJ, Hars V, et al. Hyperfractionated irradiation with or without concurrent chemotherapy for locally advanced head and neck cancer. N Engl J Med 1998;338:1798-804.
13. Cruz JJ, Ocaña A, Navarro M, Barco ED, Fonseca E. New options in the treatment of locally advanced head and neck cancer: role for induction chemotherapy. Cancer Treat Rev 2008;34:268-74

14. Forastiere AA, Goepfert H, Maor M, Pajak TF, Weber R, Morrison W, et al. Concurrent chemotherapy and radiotherapy for organ preservation in advanced laryngeal cancer. $N$ Engl J Med 2003;349:2091-8.

15. Medina JA, Rueda A, de Pasos AS, Contreras I, Cobo M, Moreno P, et al. A phase II study of concomitant boast radiation plus concurrent weekly cisplatin for locally advanced unresectable head and neck carcinomas. Radiother Oncol 2006;79:34-38.

16. Blanchard P, Baujat B, Holostenco V, Bourredjem A, Baey C, Bourhis J, et al. Meta-analysis of chemotherapy in head and neck cancer (MACH-NC): a comprehensive analysis by tumour site. Radiother Oncol 2011;100:33-40.

17. Vermorken JB, Remenar E, van Herpen C, et al. Cisplatin, fluorouracil, and docetaxel in unresectable head and neck cancer. N Engl J Med 2007; 357: 1695-704

18. Posner MR, Hershock DM, Blajman CR, et al. Cisplatin and fluorouracil alone or with docetaxel in head and neck cancer. N Engl J Med 2007; 357: 1705-15

19. Pointreau Y, Garaud P, Chapet S, et al. Randomized trial of induction chemotherapy with cisplatin and 5-fluorouracil with or without docetaxel for larynx preservation.J Natl Cancer Inst 2009; 101: 498-506.

20. Lefebvre JL, Pointreau Y, Rolland $F$ et al. Induction chemotherapy followed by either chemoradiotherapy or bioradiotherapy for larynx preservation: the TREMPLIN randomized phase II study. J Clin Oncol 2013; 31(7): 853-859.

21. Dietz A, Wichmann G, Kuhnt T, Pfreundner L, Hagen R, Scheich M, et al. Induction chemotherapy (IC) followed by radiotherapy $(R T)$ versus cetuximab plus IC and RT in advanced laryngeal/hypopharyngeal cancer resectable only by total laryngectomy-final results of the larynx organ preservation trial DeLOS=II Ann Oncol. 2018 29:2105-14. 